\title{
Pengaruh Board Diversity terhadap Manajemen Laba
}

\author{
Dewi Fatimaha, ${ }^{\mathrm{a}, *}$ \\ ${ }^{a}$ Politeknik Negeri Batam, Jurusan Manajemen Bisnis, -, Indonesia
}

\begin{abstract}
This study examines the effect on board diversity against earning management. The used samples are non-financial companies listed on the Indonesia Stock Exchange in 2010 to 2013. The data collection method using purposive sampling method and data used are panel data. The regression used is ordinary least squares regression (OLS) with fixed effect model approach and random effect model. The results showed that board diversity proxied by gender, age, education and tenure no significant effect on earnings management, whereas the diversity proxy board with tenure significant effect on earnings management. Earnings management using discretionary accruals proxy and use proxy for board gender diversity, age, minority education and tenure.
\end{abstract}

Keywords: board diversity, profit management

${ }^{*}$ Corresponding author. E-mail: - 


\section{Pendahuluan}

Laporan keuangan merupakan bagian dari proses pelaporan keuangan, laporan keuangan terdiri atas neraca, laporan laba rugi, laporan perubahan posisi keuangan, catatan serta materi penjelasan yang merupakan bagian integral dari laporan keuangan (SAK, 2012). Tujuan dari laporan keuangan adalah menyediakan informasi yang menyangkut posisi keuangan, kinerja serta perubahan posisi keuangan suatu entitas yang bermanfaat bagi sejumlah besar pengguna dalam pengambilan keputusan ekonomi (SAK, 2012). Berdasarkan tujuan tersebut, diharapkan para pengguna laporan keuangan dapat menggunakan informasi yang disajikan sebagai dasar membuat keputusan ekonomi (Kieso, Weygandt, \& Warfield, 2011).

Manajemen diberi kepercayaan oleh pemilik perusahaan atau stakeholder untuk mengoperasikan perusahaan dan melaporkan pertanggungjawabanya kepada stakeholder dalam bentuk laporan keuangan (Permana, 2012). Laporan utama untuk mengukur kinerja dalam suatu perusahaan adalah laporan laba rugi, laporan laba rugi adalah laporan yang mengukur keberhasilan operasi perusahaan selama periode waktu tertentu, menyediakan informasi yang diperlukan oleh para investor dan kreditor untuk memprediksikan jumlah, penetapan waktu, dan ketidakpastian dari arus kas masa depan (Kieso, Weygandt, dan Warfield, 2011). Pada laporan laba rugi, manajemen melakukan tindakan menaikkan (menurunkan) laba yang dilaporkan dari unit yang menjadi tanggung jawabnya yang tidak mempunyai hubungan dengan kenaikan atau penurunan profitabilitas perusahaan dalam jangka panjang (Fischer \& Rosenzweig, 1995). Tindakan ini disebut manajemen laba.

Manajemen laba dibagi menjadi dua macam yaitu: pertama, akrual diskresioner adalah akrual yang digunakan untuk mengurangi atau memperbesar laba yang dilaporkan dengan cara memilih kebijakan akuntansi oleh manajemen yang bersifat subjektif dalam rangka menurunkan atau menaikkan laba (Scott, 2009). Kedua, adalah manajemen laba melalui aktifitas riil yaitu penyimpangan dari aktifitas operasi normal perusahaan yang muncul akibat keinginan manajemen untuk memberikan pemahaman yang salah kepada stakeholder bahwa tujuan pelaporan keuangan tertentu telah dicapai melalui aktivitas operasi perusahaan (Roychowdhury, 2006).

Dalam mengatasi masalah agensi dan perilaku manajemen dalam melakukan kebijakan menaikkan atau menurunkan laba dalam laporan keuangan, maka diperlukan adanya tata kelola perusahaan yang baik dengan menerapkan konsep good corporate governance sehingga dapat mengawasi kinerja pengelola perusahaan. Salah satu isu yang berkaitan dengan corporate governance yang memberikan pengaruh terhadap perusahaan yaitu adanya keberagaman dewan (board diversity). Board diversity diukur dengan dua cara, yaitu demografi dan kognitif (Milliken \& Martins, 1996). Atribut yang diamati atau mudah-terdeteksi meliputi karakteristik demografi seperti jenis kelamin, ras, etnis dan usia; sementara non-observable atau atribut yang mendasari meliputi karakteristik kognitif seperti pendidikan, kepemilikan, latar belakang profesional, dan nilai pribadi (Milliken \& Martins, 1996).

Penelitian terkait pengaruh board diversity terhadap manajemen laba di Amerika Serikat dilakukan oleh Peni dan Vahaama (2010) tentang gender diversity terhadap manajemen laba dalam konteks perusahaan yang tergabung dalam S\&P 500 tahun 2003-2007. Penelitian tersebut menunjukkan bahwa CFO wanita memberikan pengaruh yang signifikan terhadap manajemen laba akrual, sedangkan CEO wanita tidak memberikan pengaruh yang signifikan. Penelitian lain dilakukan oleh Gavious, Segev, \& Yosef (2012) tentang pengaruh direktur wanita terhadap manajemen laba di perusahaan Israel yang terdaftar di Bursa Efek Amerika tahun 2002-2009 yang menunjukkan bahwa keberadaan salah satu dari CEO wanita ataupun CFO wanita berhubungan negatif terhadap manajemen laba.

Penelitian tentang pengaruh board diversity juga dilakukan di Indonesia yaitu oleh Darmadi (2011) untuk perusahaan yang terdaftar di BEI tahun 2007 menunjukkan bahwa gender dan nationality yang merupakan proxy dari diversity berhubungan negatif terhadap kinerja perusahaan sedangkan keberadaan eksekutif muda akan meningkatan kinerja perusahaan. Berbeda dengan hasil penelitian yang dilakukan Kusumastuti, Supatmi, \& Sastra (2007) untuk perusahaan yang terdaftar di BEI tahun 2005 menunjukkan bahwa board diversity berpengaruh terhadap nilai perusahaan.

Dari berbagai penelitian yang dilakukan sebelumnya penulis ingin mengembangkan penelitian dari Gavious, Segev \& Yosef (2012), Darmadi (2011) dan Kusumastuti, Supatmi \& Sastra (2007) tentang pengaruh board diversity terhadap manajemen laba dengan menggunakan sampel pada perusahaan di Indonesia. Adapun perbedaan penelitian ini dengan sebelumnya yang dilakukan oleh Gavious, Segev \& Yosef (2012), Darmadi (2011) dan Kusumastuti, 
Supatmi \& Sastra (2007) sebagai berikut: pertama, penelitian Gavious, Segev \& Yosef (2012) mengembangkan penelitian untuk mengetahui board diversity berbasis gender terhadap manajemen laba, maka penulis mengembangkan lima proxy yaitu pengaruh gender, age, education, tenure dan minority terhadap manajemen laba. Kedua, sistem corporate governance yang digunakan oleh Gavious, Segev \& Yosef (2012) adalah one-tier system, oleh karena itu penulis menggunakan corporate governance dengan two-tier system pada perusahaan di Indonesia. Ketiga, penelitian mengembangkan gap riset dari penelitian Darmadi (2011) tentang board diversity terhadap kinerja perusahaan dan Kusumastuti (2007) mengenai board diversity terhadap nilai perusahaan, maka penulis meneliti pengaruh board diversity terhadap manajemen laba. Keempat, sampel yang digunakan pada penelitian Gavious, Segev, \& Yosef (2012) adalah perusahaan Israel yang listing di Amerika, maka penulis menguji sampel pada perusahaan yang terdaftar di BEI tahun 2010-2013. Jadi gap riset yang diungkapkan dalam latar belakang tersebut, maka perumusan masalah yang akan diteliti adalah: bagaimana pengaruh board diversity terhadap manajemen laba. tujuan dari penelitian ini adalah untuk mengetahui pengaruh board diversity terhadap manajemen laba. Penelitian ini diharapkan akan memberikan manfaat yaitu: pertama, manfaat secara teoritis yaitu memberikan referensi tambahan di bidang akuntansi dalam pengembangan penelitian terkait dengan manajemen laba di Indonesia dan memberikan gambaran tentang pengaruh board diversity barbasis gender, age, education, tenure dan minority terhadap manjemen laba. Kedua, bagi para investor, penelitian ini diharapkan dapat memberikan tambahan informasi yang berkaitan board diversity terhadap manipulasi data laporan keuangan, untuk perusahaan yaitu memberikan masukan dalam mencermati perilaku manajemen dalam aktivitas manajemen laba yang berkaitan dengan pencapaian kompensasi bonus dan untuk peneliti yang akan datang Sebagai acuan, terutama penelitian yang berkaitan dengan pengaruh diversifikasi dewan direksi terhadap praktik manajemen laba.

\section{Kajian Literatur}

\section{Board Diversity, Manajemen Laba, Agency Theory}

Good corporate governance (GCG) secara definitif merupakan sistem yang mengatur dan mengendalikan perusahaan yang menciptakan nilai tambah untuk semua stakeholder (Monks \& Minow, 2003). Ada dua hal yang ditekankan dalam konsep ini, pertama, pentingnya hak pemegang saham untuk memperoleh informasi dengan benar dan tepat pada waktunya dan, kedua, kewajiban perusahaan untuk melakukan pengungkapan (disclosure) secara akurat, tepat waktu, transparan terhadap semua informasi kinerja perusahaan, kepemilikan, dan stakeholder.

Salah satu aspek penting dalam corporate governance adalah adanya keberagaman dewan pengurus dalam sebuah perusahaan (board diversity). Board diversity (persebaran dewan) diukur dengan dua cara, yaitu demografi dan kognitif (Milliken \& Martins, 1996). Atribut yang diamati atau mudahterdeteksi meliputi karakteristik demografi seperti jenis kelamin, ras, etnis dan usia; sementara nonobservable atau atribut yang mendasari meliputi karakteristik kognitif seperti pendidikan, kepemilikan, latar belakang profesional, dan nilai pribadi (Milliken \& Martins, 1996). Ada perspektif yang dapat digunakan untuk menjelaskan mengapa manajemen laba dilakukan oleh manajer (Sulistyanto, 2008) yaitu perspektif informasi dan oportunis. Perspektif informasi merupakan pandangan yang menyatakan bahwa manajemen laba merupakan kebijakan manajerial untuk mengungkapkan harapan pribadi manajer tentang arus kas perusahaan di masa depan. Manajemen laba dalam perspektif oportunis adalah upaya seseorang untuk mempengaruhi informasi yang disajikannya dengan memanfaatkan ketidaktahuan orang lain mengenai informasi yang sebenarnya (Sulistyanto, 2008). Kedua perspektif mempunyai hubungan sebab-akibat yang mendorong terjadinya manajemen laba.

Oleh sebab itu, manajemen laba dapat dikatakan sebagai permainan akuntansi yaitu upaya untuk menyembunyikan dan mengubah informasi dengan mempermainkan besar kecilnya angka-angka komponen laporan keuangan yang dilakukan ketika mencatat dan menyusun informasi itu. Ada dua alasan yang dapat menjelaskan mengapa laporan keuangan rawan untuk dipermainkan oleh penyusun laporan keuangan yaitu: pertama, hanya dengan memahami dan menguasai konsep-konsep akuntansi dan keuangan seseorang dapat mempermainkan informasi keuangan dengan tujuan yang ingin dicapainya. Kedua, kebebasan dalam memilih dan menggunakan metode dan prosedur akuntansi secara tidak langsung membuat standar akuntansi seakan-akan mengakomodasi atau memfasilitasi aktivitas manajerial. Sedangkan teori keagenan pertama kali dinyatakan oleh Jensen \& Meckling (1976). Dalam penelitian Jensen \& Meckling (1976), teori keagenan 
merupakan suatu kontrak antara manajer (agent) dan pemilik (principal) yaitu pemilik mendelegasikan sebagian kewenangan kepada manajer untuk melaksanakan kegiatan perusahaan dan kewenangan untuk mengambil keputusan. Berperan sebagai agen, manajemen suatu perusahaan diberi wewenang oleh pemilik untuk mengambil keputusan dan menjalankan serta mengurus jalannya perusahaan. Oleh karena itu manajemen sebagai pengelola perusahaan lebih banyak mengetahui informasi-informasi dan prospek perusahaan di masa yang akan datang dibandingkan pemilik perusahaan. Adanya pemisahaan fungsi antara pemilik dengan manajemen sebagai pengelola perusahaan dapat menimbulkan konflik. Konflik yang timbul antara pemilik dengan manajemen perusahaan disebut dengan masalah keagenan (Jensen \& Meckling, 1976).

\section{Pengaruh gender terhadap manajemen laba}

Literatur akuntansi yang ada menunjukkan bahwa kualitas pelaporan keuangan tergantung pada motif dan insentif manajerial dan perilaku oportunistik dari para eksekutif di perusahaan mempengaruhi manajemen laba. Oleh karena itu, karakteristik manajerial diakui sebagai penentu penting dari kualitas laba. Selanjutnya, literatur akuntansi perusahaan baru-baru ini menunjukkan bahwa jenis kelamin pada eksekutif dan direksi mempengaruhi tata kelola perusahaan dan kinerja keuangan perusahaan. penemuan ini menunjukkan bahwa gender pada dewan eksekutif dapat mempengaruhi perilaku manajerial.

Adanya pandangan yang berbeda tentang penyebab kesuksesan menyebabkan masih sedikitnya wanita yang ditempatkan di posisi puncak. Kesuksesan yang diperoleh pria dianggap karena kemampuan yang tinggi, sedangkan kesuksesan wanita dianggap lebih disebabkan oleh faktor keberuntungan Crawford (2006). Hal ini menyebabkan proporsi wanita dalam jabatan top manajemen masih sedikit karena kemampuan pria dianggap lebih tinggi daripada wanita.

Namun di sisi lain wanita cenderung lebih beretika dalam membuat pertimbangan dan perilakunya dibanding pria. Berdasarkan penemuan tersebut dalam penelitian ini keberadaan wanita dalam jajaran top manajemen termasuk dalam dewan komisaris dan komite audit akan memberi hambatan pada praktik manipulasi laba karena adanya keterbatan isu etika dan moral di dalamnya (Gavious, Segev, \& Yosef, 2012). Dalam penelitian ini, keberadaan keragaman berbasis gender mungkin memiliki implikasi penting untuk manajemen laba. Dengan demikian hipotesis yang akan di uji adalah:

H1: Semakin banyak proporsi wanita pada dewan direksi/dewan komisaris akan berpengaruh negatif terhadap manajemen laba

\section{Pengaruh age terhadap manajemen laba}

Menurut Hurlock (1999) dalam Kusumastuti (2007), masa dewasa seseorang dapat dibagi menjadi tiga tahap, yaitu masa dewasa dini (dewasa awal) yang dimulai dari usia 18-40 tahun, dewasa madya (dewasa tengah) yang dimulai pada usia 40-60 tahun, dan dewasa lanjut (dewasa akhir) yang dimulai pada usia 60 hingga saat kematian. Pada usia 40-45 tahun seseorang telah menapaki jenjang karir sejauh yang mereka mampu dan telah mencapai tempat yang stabil dalam karirnya ada usia 40 tahun. Usia dapat mempengaruhi kinerja seseorang dalam perusahaan yang kemudian dapat mempengaruhi nilai perusahaan dalam membuat laporan keuangan. Penelitian lain (Hambrick dan Mason, 1984) menunjukkan bahwa manajer muda cenderung melakukan strategi yang berisiko, dan mengalami kenaikan pertumbuhan dibandingkan dengan para manajer yang lebih tua. Berdasarkan uraian tersebut maka hipotesis yang dikembangkan dalam penelitian ini adalah:

$\mathrm{H} 2$ : Semakin banyak proporsi anggota dewan komisaris/direksi yang berusia 40-45 akan berpengaruh negatif terhadap manajemen laba.

\section{Pengaruh education terhadap manajemen laba}

Nurudin (2004) dalam Kususmastuti (2007), menyebutkan bahwa penelitian dari Harvard University di Amerika Serikat mengungkapkan kesuksesan tidak semata-mata ditentukan oleh pengetahuan dan keterampilan teknis (hard skill), tetapi oleh keterampilan mengelola diri dan orang lain (soft skill). Penelitian ini mengungkapkan, kesuksesan hanya ditentukan sekitar $20 \%$ dengan hard skill dan sisanya $80 \%$ dengan soft skill. Penelitian lain berpendapat bahwa dengan memiliki pengetahuan bisnis dan ekonomi yang ada, setidaknya anggota dewan memiliki kemampuan lebih baik untuk mengelola bisnis dan mengambil keputusan bisnis daripada tidak memiliki pengetahuan bisnis dan ekonomi (Kusumastuti, Supatmi, \& Sastra, 2007). Berdasarkan uraian tersebut, maka hipotesis alternatif yang diajukan dalam penelitian adalah: 
H3: Semakin banyak proporsi anggota dewan direksi/komisaris berlatar belakang pendidikan ekonomi dan bisnis akan berpengaruh negatif terhadap manajemen laba.

\section{Pengaruh minority terhadap manajemen laba}

Minoritas pada board diversity yang dimaksud adalah keberadaan etnis minoritas seperti etnis Tionghoa. Adanya etnis Tionghoa sebagai minoritas di Indonesia memberikan pengaruh dalam dunia bisnis. Menurut Kusumastuti (2007) tidak ada teori yang cukup sahih yang bisa menunjukkan dengan pasti apa yang membuat etnis Tionghoa sukses dalam bisnis. Ada pendapat mengatakan, sukses mereka didorong etos kerja tinggi, khas semangat kaum minoritas, sikap hemat, dan disiplin yang merupakan inti dari filosofi bisnis juga menjadi ciri khas kehidupan warga keturunan Tionghoa.

Karakteristik budaya Tionghoa menurut Setyawan (2005) antara lain kekuasaan dan otokrasi (power and autocracy), kekeluargaan (familism), jaringan relasi (guanxi), harga diri dan wibawa (face and prestige), serta fleksibel dan bertahan hidup (flexibility and endurance). Dengan karakteristik inilah dianggap etnis Tionghoa di Indonesia memiliki pengaruh terhadap dunia perekonomian, terutama sektor bisnis. Berdasarkan uraian tersebut, maka hipotesis alternatif yang dirumuskan dalam penelitian ini adalah:

H4: Semakin banyak proporsi minority (etnis Tionghoa) dalam dewan komisaris/direksi akan berpengaruh negatif terhadap manajemen laba.

\section{Pengaruh tenure terhadap manajemen laba}

Penelitian Pfeffer (1983) menyarankan bahwa adanya komposisi demografi pada kelompok dewan bisa menjadi penentu penting dari proses dan kinerja suatu perusahaan. Tim pada top manajemen yang beragam menyebabkan kenaikan kreativitas dan meningkatkan kemampuan beradaptasi pada pembuatan keputusan strategis (Murray, 1989 dalam Tihanyi et al, 2000). Tim manajemen puncak dengan keragaman pada usia, masa jabatan, pendidikan atau latar belakang fungsional dapat memiliki beragam nilai-nilai, pengalaman, dan keyakinan (Tihanyi et al, 2000).

Secara umum bukti kuat tentang pengaruh tenure diversity terhadap rendahnya tingkat integrasi sosial, rendahnya komunikasi dalam suatu perusahaan (Williams \& O'Reilly, 1998). Alasan mengenai diversifikasi umur juga berlaku untuk diversifikasi kepemilikan pada tim manajemen puncak. Lawrence (1997) menyebutkan bahwa persepsi eksekutif dalam kaitanya dengan umur keterlibatan dalam suatu perusahann mempengaruhi proses pengambilan keputusan. Seorang dewan direksi baru membutuhkan waktu berkisar antara tiga dan lima tahun untuk memperoleh pemahaman yang memadai mengenai perusahaan (Kesner, 1988). Berdasarkan uraian tersebut, maka hipotesis alternatif yang dirumuskan dalam penelitian ini adalah:

H5: Masa jabatan anggota dewan komisaris/direksi akan berpengaruh negatif terhadap manajemen laba.

\section{Metode Penelitian}

Metode penelitian yang digunakan adalah metode pendekatan kuantitatif. Metode pendekatan kuantitatif ini dipilih untuk mengembangkan model penelitian, teori atau hipotesis yang berkaitan dengan variabel yang akan diteliti. Model analisis dalam penelitian ini yaitu regresi ordinary least square (OLS) untuk menguji hipotesis, model penelitian adalah sebagai berikut:

$$
\begin{aligned}
M L= & \alpha+\beta 1 \text { GENit }+\beta 2 \text { AGEit }+\beta 3 \text { EDUit }+\beta 4 \\
& \text { TENit }+\beta 5 \text { MINOit }+\beta 6 \text { ROAit }+\beta 7 \text { LEVit }+ \\
& \text { cit }
\end{aligned}
$$

\section{Operasional Variabel}

Variabel dependen pada penelitian ini adalah manajemen laba. Manejemen laba menggunakan proxy akrual diskresioneri yang menggunakan model Jones (1991) yang dimodifikasi. Model ini dianggap memberikan hasil yang paling baik dan kuat dalam mendeteksi adanya manajemen laba (Dechow, Sloan, \& Sweeney, 1995)

Menghitung akrual diskrisioneri:

Penggunaan diskresionary accrual dihitung dengan Model Jones dimodifikasi sebagai berikut:

TACt $=$ NIt - CFOt

Nilai Total accrual (TA) yang diestimasi dengan persamaan regresi OLS sebagai berikut:

$$
\frac{T A C t}{T A t-1}=\alpha 1+\frac{1}{T A t-1}+\alpha 2 \frac{(\triangle R E V t)}{T A t-1}+\alpha 3 \frac{(P P E t)}{T A t-1}+\varepsilon \ldots \ldots \ldots
$$

Dengan menggunakan koefisien regresi di atas nilai non diskesionery accrual (NDA) dapat dihitung dengan rumus:

$$
\text { NDAt }=\alpha 1+\frac{1}{T A t-1}+\alpha 2 \frac{(\triangle R E V t-\triangle R E C t)}{T A t-1}+\alpha 3 \frac{(P P E t)}{T A t-1} \ldots \ldots
$$


Selanjutnya discresionary accrual (DA) dapat dihitung sebagai berikut:

$D A C t=\frac{T A C t}{T A t-1}-N D A$

Keterangan:

$\mathrm{DACt}=$ Akrual diskrioner perusahaan pada periode $\mathrm{t}$

TACt $=$ Akrual diskrioner total perusahaan dalam periode $\mathrm{t}$

TAt-1 = Aset total perusahaan pada akhir periode $\mathrm{t}-1$

NDAt = Non discreonary accruals perusahaan pada perode $\mathrm{t}$

$\triangle \mathrm{REV}=$ perubahan pendapatan perusahaan antara periode $\mathrm{t}-1$ dan $\mathrm{t}$

PPEt = Aset tetap perusahaan (gross property, plant, and equipment) pada periode $\mathrm{t}$

$\triangle \mathrm{RECt}=$ perubahan pada piutang perusahaan antara periode $\mathrm{t}-1$ dan $\mathrm{t}$

NIt = laba bersih setelah pajak perusahaan dalam periode $\mathrm{t}$

CFOt $=$ arus kas operasi perusahaan dalam periode $\mathrm{t}$

$\alpha 1, \alpha 2, \alpha 3=$ koefisien regresi

$\varepsilon \quad=$ koefisen eror

Variabel independen pada penelitian ini adalah board diversity. Dalam penelitian ini board diversity diukur dengan lima diversity yaitu gender, age, education, minority (etnik) dan tenure (masa perikatan) dewan.

Variabel Kontrol pada penelitian ini meliputi ROA dan leverage. ROA adalah salah satu bentuk dari rasio profitabilitas untuk mengukur kemampuan perusahaan dalam menghasilkan laba. ROA yang positif menunjukan bahwa dari total aktiva yang dipergunakan untuk operasi perusahaan mampu memberikan laba bagi perusahaan, sebaliknya jika ROA negatif menunjukan total aktiva yang dipergunakan tidak memberikan keuntungan. Leverage adalah kemampuan perusahaan atas penggunaan utang untuk membiayai investasi.

Tabel 1

Variabel dan Pengukuran

\begin{tabular}{lll}
\hline Variabel & \multicolumn{1}{c}{ Keterangan } & \multicolumn{1}{c}{ Kriteria pengukuran } \\
\hline ML & Manajemen laba & $\begin{array}{l}\text { Diskresioner total akrual model } \\
\text { Jones (1991) yang di modifikasi } \\
\text { GEN }\end{array}$ \\
& $\begin{array}{l}\text { Gender dalam hal ini } \\
\text { adalah wanita dari } \\
\text { dewan }\end{array}$ & $\begin{array}{l}\text { wanita } / \text { direksi(komisaris) } \\
\text { direksi/komisaris }\end{array}$ \\
&
\end{tabular}

\begin{tabular}{|c|c|c|}
\hline AGE & $\begin{array}{l}\text { Umur dari dewan } \\
\text { direksi/komisaris }\end{array}$ & $\begin{array}{l}\% \text { direksi(komisaris) dengan } \\
\text { umur } 40-45 / \Sigma \text { direksi(komisaris) }\end{array}$ \\
\hline EDU & $\begin{array}{l}\text { Latar belakang } \\
\text { pendidikan dari dewan } \\
\text { direksi/komisaris }\end{array}$ & $\begin{array}{l}\% \Sigma \text { direksi(komisaris)dengan } \\
\text { pendidikan } \\
\text { bisnis } / \Sigma \text { direksi(komisaris) }\end{array}$ \\
\hline TEN & $\begin{array}{l}\text { Tenure (masa jabatan) } \\
\text { dari dewan } \\
\text { direksi/komisaris }\end{array}$ & $\begin{array}{l}\% \Sigma \text { direksi(komisaris) dengan } \\
\text { masa jabatan } 5 \text { tahun } \\
/ \Sigma \text { direksi(komisaris) }\end{array}$ \\
\hline MINO & Minority (etnis) & $\begin{array}{l}\% \Sigma \text { direksi(komisaris) etnis } \\
\text { tionghoa/ } / \Sigma \text { direksi(komisaris) }\end{array}$ \\
\hline ROA & Return on Asset & Laba setelah pajak/Total Aset \\
\hline LEV & Leverage & Hutang/total Aset \\
\hline$\alpha$ & konstanta & \\
\hline$\beta$ & koefisien regresi & \\
\hline & nama perusahaan & \\
\hline
\end{tabular}

\section{Data dan Sampel}

Penelitian ini menggunakan data sekunder berupa annual report tahun 2010-2013. Populasi dalam penelitian ini adalah seluruh perusahaan yang tercatat di Bursa Efek Indonesia (BEI) tahun 2010-2013. Jumlah sampel dalam penelitian ini sebanyak 96 perusahaan pertahun sehingga total sampel sebanyak 384 observasi (firm-year). Hasil tersebut diperoleh dari perusahaan yang listing selama periode pengamatan sebanyak 507 perusahaan dikurangi kriteria sebagai berikut: perusahaan yang bergerak dalam industri keuangan dan lembaga keuangan sebanyak 87 perusahaan, perusahaan yang melakukan merger dan initial public offering sebanyak 105 perusahaan, perusahaan yang laporan keuangan dan tahunannya tidak lengkap sebanyak 72 perusahaan, perusahaan yang menggunakan mata uang selain rupiah sebanyak 42 perusahaan, perusahaan yang pencatatan laporan keuangannya selain 1 Januari-31 Desember sebanyak 2 perusahaan, perusahaan mengalami kerugian selama periode pengamatan sebanyak 69 perusahaan dan perusahaan yang tidak lengkap struktur board diversity sebanyak 34 perusahaan.

\section{Pembahasan}

Statistik deskriptif dalam penelitian ini berisi profil subjek penelitian dan karakteristik data yang digunakan. Hasil pengujian statistik deskriptif disajikan dalam Tabel 2. Berdasarkan hasil pengujian statistik deskriptif pada Tabel 2 dapat diketahui bahwa variabel dependen berupa manajemen laba diperoleh nilai rata-rata tingkat perusahaan melakukan incomeincreasing $1,20 \%$ dari laba. Perusahaan melakukan income-decreasing dengan presentase maksimum 
sebesar $100,21 \%$ dari laba, sedangkan maksimum income-increasing dilakukan sebesar $58,20 \%$ dari laba dengan menggunakan sampel observasi 384 perusahaan.

Tabel 2

Hasil Uji Statistik Deskriptif

\begin{tabular}{lrrrrl}
\hline $\begin{array}{c}\text { Nama } \\
\text { Variabel }\end{array}$ & $\begin{array}{c}\text { Observation } \\
\text { s }\end{array}$ & $\begin{array}{c}\text { Mea } \\
\text { n }\end{array}$ & Maxi & Min & $\begin{array}{c}\text { Std. } \\
\text { Dev. }\end{array}$ \\
\hline EM & 384 & 0.012 & 0.582 & -1.215 & 0.138 \\
GEND & 384 & 0.120 & 0.538 & 0.000 & 0.134 \\
AGE & 384 & 0.095 & 1.000 & 0.000 & 0.142 \\
EDU & 384 & 0.486 & 1.000 & 0.000 & 0.193 \\
MINO & 384 & 0.439 & 1.000 & 0.000 & 0.283 \\
TENU & 384 & 0.463 & 1.000 & 0.000 & 0.310 \\
ROA & 384 & 0.082 & 0.410 & 0.000 & 0.066 \\
LEV & 384 & 0.433 & 1.049 & 0.037 & 0.192 \\
\hline
\end{tabular}

Keterangan: Tabel ini merupakan hasil uji statistik deskriptif. Variabel dependen berupa Manajemen Laba, sedangkan variabel independennya yaitu GENDER, AGE, EDUCATION, MINORITY dan TENURE.

Penjelasan dari variabel tersebut adalah EM (Earning Management) = Akrual diskresioner dengan model jones (1991) yang dimodifikasi

,GEND = presentase jumlah direksi/komisaris wanita/jumlah dewan direksi/komisaris, AGE = presentase jumlah direksi/komisaris dengan umur 40-45tahun/jumlah dewan direksi/komisaris, EDU = presentase jumlah direksi/komisaris dengan pendidikan ekonomi(bisnis)/jumlah dewan direksi/komisaris, $\mathrm{MINO}=$ presentase jumlah direksi/komisaris dengan etnis tionghoa/jumlah dewan direksi/komisaris, TENU = presentase jumlah direksi/komisaris dengan masa jabatan lebih dari 5 tahun/jumlah dewan direksi/komisaris, ROA = laba setelah pajak/total aset, LEV = Piutang jangka panjang/total aset

Dari Tabel 2, variabel independen yaitu board diversity dideskripsikan sebagai berikut: keberadaan wanita pada perusahaan menunjukkan bahwa keberadaan wanita di jajaran dewan masih tergolong rendah, ditunjukkan dengan adanya nilai rata-rata sebesar $12 \%$ saja. Keberadaan dewan dengan umur 40-45 tahun menunjukkan rata-rata sebesar 9,5\% dari dewan direksi/komisaris, hal ini menunjukkan bahwa keberadaan dewan dengan umur 40-45 juga tergolong rendah.

Nilai rata-rata dewan dengan latar belakang pedidikan ekonomi dan bisnis sebesar $48,6 \%$ dari dewan direksi/komisaris, Ini menunjukkan bahwa latar belakang pendidikan sangat tinggi. Keberadaan etnis Tionghoa di jajaran direksi/komisaris ditunjukkan dengan nilai rata-rata etnis Tionghoa sebesar 43,9\% dari keberadaan dewan. Keberadaan dewan dengan masa jabatan lebih dari 5 tahun ditunjukkan dengan nilai rata-rata $46,3 \%$ dewan direksi/komisaris, ini menunjukkan bahwa dewan dengan pengalaman menjabat lebih dari 5 tahun juga sangat tinggi.

Variabel kontrol penelitian ini ada 2, yaitu ROA dan leverage. Berdasarkan Tabel 2, ROA memiliki nilai rata-rata tingkat pengembalian aset $8,2 \%$ sedangkan nilai rata-rata leverage adalah 0,433 ini menunjukkan pengembalian hutang terhadap total aset perusahaan adalah $43,3 \%$.

Penelitian ini bertujuan untuk mengetahui pengaruh variabel independen dan variabel dependen dengan menggunakan data panel. Pengolahan menggunakan data panel tidak memerlukan pengujian normalitas dan autokorelasi sehingga tidak perlu dilakukan kedua pengujian tersebut (Nachrowi dan Usman, 2006). Untuk itu asumsi yang harus dipenuhi dalam model data panel adalah: Pengujian ada tidaknya multikolinearitas dengan melihat nilai variance inflation factor (VIF), dan mengetahui ada tidaknya heterokedastisitas dengan melihat nilai Obs*RSquared pada uji white heterokedastisitas. Untuk mengestimasi model regresi data panel dapat menggunakan tiga pendekatan, yaitu: pooled least squared model, fix effect model, random effect model.

\section{Pengaruh gender terhadap manajemen laba}

Tabel 3

Hasil Uji Regresi Pengaruh Gender terhadap Manajemen Laba

\begin{tabular}{|c|c|c|c|c|c|}
\hline \multirow{2}{*}{$\begin{array}{c}\mathrm{ML}=\alpha+\beta_{1} \text { GENit } \\
+\beta 2 \text { ROAit }+\beta 3 \\
\text { LEVit }+ \text { sit } \\
\text { Variable } \\
\text { Independen }\end{array}$} & \multirow{2}{*}{$\begin{array}{c}\text { ekspe } \\
\mathrm{k} \\
\text { tanda }\end{array}$} & \multicolumn{4}{|c|}{ Variabel Dependen } \\
\hline & & $\begin{array}{c}\text { Koefisie } \\
\text { n }\end{array}$ & $\begin{array}{c}\mathrm{t}- \\
\text { Statistic }\end{array}$ & $\mathrm{p}$-value & VIF \\
\hline GEND (H1) & - & 0.10902 & 0.87468 & 0.19125 & $\begin{array}{r}1.1406 \\
8\end{array}$ \\
\hline ROA & \pm & 1.00334 & 6.55347 & $\begin{array}{r}* * * 0.000 \\
0\end{array}$ & $\begin{array}{r}1.2224 \\
3\end{array}$ \\
\hline LEV & \pm & -0.02180 & -0.33420 & 0.36925 & $\begin{array}{r}1.2088 \\
0\end{array}$ \\
\hline $\begin{array}{l}\text { Constanta } \\
\text { N } \\
\text { Prob. Chi- } \\
\text { Square(3) }\end{array}$ & & -0.07332 & -2.04676 & $\begin{array}{r}0.02080 \\
384 \\
0.1437\end{array}$ & \\
\hline $\mathrm{R}$-squared & & & & 0.58340 & \\
\hline Adjusted R-squared & & & & 0.44015 & \\
\hline F-statistic & & & & 4.07253 & \\
\hline Prob(F-statistic) & & & & $\begin{array}{r}* * * 0.000 \\
0\end{array}$ & \\
\hline Hasil Uji Hausmann 1 & & & & Fixed & \\
\hline $\begin{array}{l}\text { ***Signifikan pada } \\
\text { Keterangan: Tabel ini } \\
\text { Manajemen Laba. De } \\
\text { Variabel dependen ya } \\
\text { gender dan variabel } \mathrm{k} \\
\text { adalah Manajemen la } \\
=\text { presentase jumlah d } \\
=\text { laba setelah pajak/tc }\end{array}$ & $\begin{array}{l}\text { vel } 1 \% \text {. } \\
\text { nerupak: } \\
\text { zan metc } \\
\text { u Manaj } \\
\text { trol nya } \\
=\text { akrua } \\
\text { eksi/kon } \\
\text { al aset, I }\end{array}$ & $\begin{array}{l}\text { Signifikan } \mathrm{p} \\
10 \% \\
\text { hasil uji reg } \\
\text { fix effect s } \\
\text { len Laba, se } \\
\text { OA dan lev } \\
\text { liskresioner } \\
\text { aris wanita/ } \\
\mathrm{V}=\text { Piutang }\end{array}$ & $\begin{array}{l}\text { da Level 5\% } \\
\text { si H1 Penga } \\
\text { elah dilakuk } \\
\text { ingkan varia } \\
\text { age. Penjela } \\
\text { nes } 1991 \text { ya } \\
\text { mlah dewan } \\
\text { ingka panjar }\end{array}$ & $\begin{array}{l}\text { Signifikan } \\
\text { gender Te } \\
\text { uji Hausma } \\
\text { independer } \\
\text { dari variab } \\
\text { di modifika } \\
\text { reksi/komis } \\
\text { otal aset. }\end{array}$ & $\begin{array}{l}\text { a level } \\
\text { Idap } \\
\text { ya yaitu } \\
\text { tersebut } \\
\text { GEND } \\
\text { s, ROA }\end{array}$ \\
\hline
\end{tabular}

Berdasarkan hasil uji regresi pada Tabel 3, hipotesis pertama $\mathrm{H} 1$ tidak dapat didukung. Hal ini dilihat dari nilai p-value (H1) sebesar 0,19125. Hal ini menunjukkan bahwa gender tidak berpengaruh terhadap adanya manajemen laba. Jadi perusahaan melakukan manajemen laba tidak tergantung pada ada atau tidaknya wanita dalam dewan direksi atau komisaris. Hasil penelitian ini mendukung hasil penelitian yang dilakukan oleh Peni dan Vahaama (2010) bahwa CEO wanita tidak berpengaruh terhadap manajemen laba. Penelitian lain berkaitan dengan 
gender diversity terhadap manajemen laba dilakukan oleh Gavious, Segev \& Yosef (2012) menunjukkan bahwa keberadaan CEO wanita atau CFO wanita tidak berhubungan secara signifikan pada manajemen laba.

Keberadaan wanita sebagai pimpinan perusahaan (direksi/komisaris) yang cenderung rendah, sehingga disimpulkan bahwa perusahaan melakukan manajemen laba tidak tergantung pada pimpinan perusahaan (direksi) wanita maupun pria.

\section{Pengaruh age terhadap manajemen laba}

Hipotesis $2(\mathrm{H} 2)$ mengajukan bahwa semakin banyak proporsi anggota dewan komisaris/direksi yang berusia 40-45 akan berpengaruh negatif terhadap manajemen laba. Hasil pengujian disajikan dalam Tabel 4 adalah sebagai berikut:

Tabel 4

Hasil Uji Regresi Pengaruh Age terhadap Manajemen Laba

\begin{tabular}{|c|c|c|c|c|c|}
\hline \multirow{2}{*}{$\begin{array}{c}\mathrm{ML}=\alpha+\beta_{1} \\
\text { AGEit }+\beta 2 \text { ROAit } \\
+\beta 3 \text { LEVit }+\varepsilon i t \\
\text { Variable } \\
\text { Independen }\end{array}$} & \multirow{2}{*}{$\begin{array}{l}\text { ekspek } \\
\text { s tanda }\end{array}$} & \multicolumn{4}{|c|}{ Variabel Dependen } \\
\hline & & $\begin{array}{c}\text { Koefisie } \\
n\end{array}$ & $\begin{array}{c}\mathrm{t}- \\
\text { Statistic }\end{array}$ & $\mathrm{p}$-value & VIF \\
\hline $\operatorname{AGE}(\mathrm{H} 2)$ & - & -0.05550 & -0.70862 & 0.23955 & $\begin{array}{r}1.0096 \\
4\end{array}$ \\
\hline ROA & \pm & 0.99830 & 6.52365 & $\begin{array}{r}* * * 0.000 \\
0\end{array}$ & $\begin{array}{r}1.1654 \\
9\end{array}$ \\
\hline LEV & \pm & -0.02005 & -0.30757 & 0.37930 & $\begin{array}{r}1.1755 \\
4\end{array}$ \\
\hline $\begin{array}{l}\text { Constanta } \\
\mathrm{N}\end{array}$ & & -0.05528 & -1.60596 & $\begin{array}{r}0.05470 \\
384\end{array}$ & \\
\hline $\begin{array}{l}\text { Prob. Chi- } \\
\text { Square(3) }\end{array}$ & & & & 0.2078 & \\
\hline $\mathrm{R}$-squared & & & & 0.58302 & \\
\hline Adjusted R-squared & & & & 0.43963 & \\
\hline F-statistic & & & & 4.06610 & \\
\hline Prob(F-statistic) & & & & $\begin{array}{r}* * * 0.000 \\
0\end{array}$ & \\
\hline Hasil Uji Hausmann & & & & Fixed & \\
\hline \multicolumn{6}{|c|}{$\begin{array}{l}\text { ***Signifikan pada level 1\%.**Signifikan pada Level 5\%. *Signifikan pada level } \\
10 \% \\
\text { Keterangan: Tabel ini merupakan hasil uji regresi H2 Pengaruh age Terhadap } \\
\text { Manajemen Laba. Dengan metode fix effect setelah dilakukan uji Hausmann. } \\
\text { Variabel dependen yaitu Manajemen Laba, sedangkan variabel independennya yaitu } \\
\text { age dan variabel kontrol nya ROA dan leverage. Penjelasan dari variabel tersebut } \\
\text { adalah Manajemen laba = akrual diskresioner jones 1991 yang di modifikasi, AGE = } \\
\text { presentase jumlah direksi/komisaris dengan umur 40-45 th/jumlah dewan } \\
\text { direksi/komisaris, ROA = laba setelah pajak/total aset, LEV = Piutang jangka } \\
\text { panjang/total aset. }\end{array}$} \\
\hline
\end{tabular}

Berdasarkan hasil uji regresi pada Tabel 4, hipotesis kedua (H2) tidak dapat didukung ditunjukkan dengan nilai p-value sebesar 0,23955 . Hal ini menunjukkan bahwa age tidak berpengaruh terhadap adanya manajemen laba. Penelitian Hurlock (1999) sebagaimana dikutip oleh Kusumastuti, Supatmi \& Sastra (2007), ketika memasuki usia 40-45 tahun, seseorang telah menapaki jenjang karir sesuai kemampuannya dan telah mencapai tempat yang stabil dalam karirnya pada usia 40 tahun.

Hasil uji hipotesis pada Tabel 4 menunjukkan tidak ada pengaruh keberadaan dewan dengan umur direksi yang muda, usia produktif (40-45) maupun lebih tua dengan adanya praktik manajemen laba.

\section{Pengaruh education terhadap manajemen laba}

Hipotesis 3 (H3) bahwa semakin banyak proporsi anggota dewan direksi/komisaris berlatar belakang pendidikan ekonomi dan bisnis akan berpengaruh negatif terhadap manajemen laba. Hasil pengujian disajikan dalam Tabel 5 adalah sebagai berikut:

Tabel 5

Hasil Uji Regresi Pengaruh Education terhadap Manajemen Laba

\begin{tabular}{|c|c|c|c|c|c|}
\hline \multirow{2}{*}{$\begin{array}{c}\text { ML }=\alpha+\beta_{1} \\
\text { EDUit }+\beta 2 \text { ROAit } \\
+\beta 3 \text { LEVit }+ \text { zit } \\
\text { Variable } \\
\text { Independen }\end{array}$} & \multirow{2}{*}{$\begin{array}{c}\text { Ekspek } \\
\text { s tanda }\end{array}$} & \multicolumn{4}{|c|}{ Variabel Dependen } \\
\hline & & $\begin{array}{c}\text { Koefisie } \\
\mathrm{n}\end{array}$ & $\begin{array}{c}\mathrm{t}- \\
\text { Statistic }\end{array}$ & $\mathrm{p}$-value & VIF \\
\hline $\mathrm{EDU}(\mathrm{H} 3)$ & - & -0.01010 & $\begin{array}{r}- \\
0.09808\end{array}$ & 0.46095 & $\begin{array}{r}1.0022 \\
1\end{array}$ \\
\hline ROA & \pm & 0.99956 & 6.46332 & $\begin{array}{r}* * * 0.000 \\
0\end{array}$ & $\begin{array}{r}1.1657 \\
0\end{array}$ \\
\hline LEV & \pm & -0.01736 & 0.26654 & 0.39500 & $\begin{array}{r}1.1665 \\
0\end{array}$ \\
\hline Constanta & & -0.05692 & 0.97723 & 0.16465 & \\
\hline $\mathrm{N}$ & & & & 384 & \\
\hline $\begin{array}{l}\text { Prob. Chi- } \\
\text { Square(3) }\end{array}$ & & & & 0.1963 & \\
\hline $\mathrm{R}$-squared & & & & 0.58230 & \\
\hline Adjusted R-squared & & & & 0.43866 & \\
\hline F-statistic & & & & 4.05407 & \\
\hline Prob(F-statistic) & & & & $\begin{array}{r}* * * 0.000 \\
0\end{array}$ & \\
\hline Hasil Uji Hausmann T & & & & Fixed & \\
\hline \multicolumn{6}{|c|}{$\begin{array}{l}\text { ***Signifikan pada level } 1 \% \text {.**Signifikan pada Level } 5 \% \text {. *Signifikan pada level } \\
10 \% \\
\text { Keterangan: Tabel ini merupakan hasil uji regresi H3 Pengaruh education Terhadap } \\
\text { Manajemen Laba. Dengan metode fix effect setelah dilakukan uji Hausmann. } \\
\text { Variabel dependen yaitu Manajemen Laba, sedangkan variabel independennya yaitu } \\
\text { age dan variabel kontrol nya ROA dan leverage. Penjelasan dari variabel tersebut } \\
\text { adalah Manajemen laba = akrual diskresioner jones } 1991 \text { yang di modifikasi, } \\
\text { Education = presentase jumlah direksi/komisaris dengan latar belakang ekonomi } \\
\text { bisnis/jumlah dewan direksi/komisaris, ROA = laba setelah pajak/total aset, LEV } \\
\text { Piutang jangka panjang/total aset. }\end{array}$} \\
\hline
\end{tabular}

Berdasarkan hasil uji regresi pada Tabel 5, hipotesis ketiga (H3) tidak dapat didukung ditunjukkan dengan nilai p-value sebesar 0,46095. Hal ini menunjukkan bahwa education tidak berpengaruh terhadap adanya manajemen laba. Menurut penelitian Kusumastuti, Supatmi \& Sastra (2007) tentang board diversity terhadap nilai perusahaan, menemukan bahwa dewan dengan memiliki pengetahuan bisnis dan ekonomi yang ada, setidaknya anggota dewan memiliki kemampuan lebih baik untuk mengelola bisnis dan mengambil keputusan bisnis daripada tidak memiliki pengetahuan bisnis dan ekonomi.

Keberadaan pimpinan perusahaan (direksi/komisaris) dengan latar belakang pendidikan ekonomi dan bisnis atau pendidikan lain tidak mempengaruhi adanya praktik manajemen laba pada perusahaan. 
Pengaruh minority terhadap manajemen laba

Tabel 6

Hasil Uji Regresi Pengaruh Minority terhadap Manajemen Laba

\begin{tabular}{|c|c|c|c|c|c|}
\hline \multirow{2}{*}{$\begin{array}{c}\mathrm{ML}=\alpha+\beta_{1} \\
\text { MINOit }+\beta 2 \\
\text { ROAit }+\beta 3 \text { LEVit } \\
+ \text { zit } \\
\text { Variable } \\
\text { Independen }\end{array}$} & \multirow{2}{*}{$\begin{array}{l}\text { ekspek } \\
\text { s tanda }\end{array}$} & \multicolumn{4}{|c|}{ Variabel Dependen } \\
\hline & & $\begin{array}{c}\text { Koefisie } \\
\mathrm{n}\end{array}$ & $\begin{array}{c}\mathrm{t}- \\
\text { Statistic } \\
\end{array}$ & $\mathrm{p}$-value & VIF \\
\hline MINO (H5) & - & 0.06638 & 0.60521 & 0.27275 & $\begin{array}{r}1.0090 \\
1\end{array}$ \\
\hline ROA & \pm & 0.98958 & 6.44204 & $\begin{array}{r}* * * * 0.000 \\
0\end{array}$ & $\begin{array}{r}1.1647 \\
1\end{array}$ \\
\hline LEV & \pm & -0.01922 & -0.29505 & 0.38410 & 1.1744 \\
\hline $\begin{array}{l}\text { Constanta } \\
\mathrm{N}\end{array}$ & & -0.08931 & -1.57857 & $\begin{array}{r}-0.04466 \\
384\end{array}$ & \\
\hline $\begin{array}{l}\text { Prob. Chi- } \\
\text { Square(3) }\end{array}$ & & & & 0.0535 & \\
\hline R-squared & & & & 0.58282 & \\
\hline Adjusted & & & & & \\
\hline F-statistic & & & & $\begin{array}{r}4.06279 \\
\end{array}$ & \\
\hline Prob(F-statistic) & & & & & \\
\hline Hasil Uji Hausmann & & & & & \\
\hline \multicolumn{6}{|c|}{$\begin{array}{l}\text { ***Signifikan pada level } 1 \% . * * \text { Signifikan pada Level } 5 \% . * \text { Signifikan pada level } \\
10 \% \\
\text { Keterangan: Tabel ini merupakan hasil uji regresi H4 Pengaruh minority Terhadap } \\
\text { Manajemen Laba. Dengan metode fix effect setelah dilakukan uji Hausmann. } \\
\text { Variabel dependen yaitu Manajemen Laba, sedangkan variabel independennya yaitu } \\
\text { age dan variabel kontrol nya ROA dan leverage. Penjelasan dari variabel tersebut } \\
\text { adalah Manajemen laba = akrual diskresioner jones 1991 yang di modifikasi, } \\
\text { Minority = presentase jumlah direksi/komisaris dengan etnis tionghoa/jumlah dewan } \\
\text { direksi/komisaris, ROA = laba setelah pajak/total aset, LEV = Piutang jangka } \\
\text { panjang/total aset. }\end{array}$} \\
\hline
\end{tabular}

Uji hipotesis kedua (H4) menunjukkan bahwa minority tidak berpengaruh signifikan terhadap adanya manajemen laba. Penelitian yang dilakukan oleh Kusumastuti, Supatmi \& Sastra (2007), menemukan bahwa dewan direksi atau komisaris dengan latar belakang etnis Tionghoa tidak berpengaruh signifikan terhadap kinerja perusahaan.

Perusahaan yang memiliki anggota dewan etnis Tionghoa, merupakan perusahaan keluarga, di mana anggota dewan adalah anggota keluarga sendiri. Jadi, perusahaan merekrut orang-orang yang masih saudara dengan alasan supaya perusahaan tetap berada di bawah kekuasaan keluarga sendiri, sehingga keberadaan dewan etnis Tionghoa pada jajaran manajemen akan melakukan praktek manajemen laba untuk menjaga reputasi perusahaan tersebut.

\section{Pengaruh tenure terhadap manajemen laba}

Uji hipotesis kedua (H5) menunjukkan bahwa tenure berpengaruh positif terhadap adanya manajemen laba. Penelitian ini medukung penelitian terdahulu yang dilakukan oleh Kesner (1988) menyebutkan bahwa persepsi eksekutif dalam kaitanya dengan umur keterlibatan dalam suatu perusahaan mempengaruhi proses pengambilan keputusan.
Tabel 7

Hasil Uji Regresi Pengaruh Tenure terhadap Manajemen Laba

\begin{tabular}{|c|c|c|c|c|c|}
\hline \multirow{2}{*}{$\begin{array}{c}\mathrm{ML}=\alpha+\beta_{1} \\
\text { TENUit }+\beta 2 \\
\text { ROAit }+\beta 3 \text { LEVit } \\
+ \text { zit } \\
\text { Variable } \\
\text { Independen }\end{array}$} & \multirow{2}{*}{$\begin{array}{l}\text { ekspek } \\
\text { s tanda }\end{array}$} & \multicolumn{4}{|c|}{ Variabel Dependen } \\
\hline & & $\begin{array}{c}\text { Koefisie } \\
\text { n }\end{array}$ & $\begin{array}{c}\mathrm{t}- \\
\text { statistic }\end{array}$ & p-value & VIF \\
\hline TENU (H5) & - & -0.06490 & 1.51771 & $* * 0.0651$ & $\begin{array}{r}1.0225 \\
3\end{array}$ \\
\hline ROA & \pm & 0.99702 & 6.53599 & $\begin{array}{r}* * * 0.000 \\
0\end{array}$ & $\begin{array}{r}1.1905 \\
8\end{array}$ \\
\hline LEV & \pm & -0.02079 & 0.32039 & 0.37445 & \multirow[t]{9}{*}{$\begin{array}{r}1.1685 \\
4\end{array}$} \\
\hline \multicolumn{2}{|l|}{ Constanta } & \multirow[t]{6}{*}{-0.03009} & \multirow{2}{*}{0.76928} & 0.22120 & \\
\hline \multicolumn{2}{|l|}{$\mathrm{N}$} & & \multirow{2}{*}{\multicolumn{2}{|c|}{$\begin{array}{r}384 \\
0.1799\end{array}$}} & \\
\hline \multicolumn{2}{|l|}{$\begin{array}{l}\text { Prob. Chi- } \\
\text { Square(3) }\end{array}$} & & & & \\
\hline \multirow{2}{*}{\multicolumn{2}{|c|}{$\begin{array}{l}\mathrm{R} \text {-squared } \\
\text { Adjusted R-squared }\end{array}$}} & & & \\
\hline & & & \multicolumn{2}{|r|}{0.44314} & \\
\hline \multicolumn{2}{|l|}{ F-statistic } & & \multirow{2}{*}{\multicolumn{2}{|c|}{$\begin{array}{r}4.11011 \\
* * * 0000\end{array}$}} & \\
\hline \multicolumn{3}{|l|}{ Prob(F-statistic) } & $\begin{array}{r}* * * 0.000 \\
0\end{array}$ & & \\
\hline \multicolumn{3}{|c|}{ Hasil Uji Hausmann Test } & \multicolumn{2}{|c|}{ Fixed } & \\
\hline \multicolumn{6}{|c|}{$\begin{array}{l}\text { ***Signifikan pada level 1\%.**Signifikan pada Level 5\%. *Signifikan pada level } \\
10 \% \\
\text { Keterangan: Tabel ini merupakan hasil uji regresi H5 Pengaruh tenure Terhadap } \\
\text { Manajemen Laba. Dengan metode fix effect setelah dilakukan uji Hausmann. } \\
\text { Variabel dependen yaitu Manajemen Laba, sedangkan variabel independennya yaitu } \\
\text { age dan variabel kontrol nya ROA dan leverage. Penjelasan dari variabel tersebut } \\
\text { adalah Manajemen laba = akrual diskresioner jones } 1991 \text { yang di modifikasi, Tenure } \\
=\text { presentase jumlah direksi/komisaris dengan masa jabatan lebih dari } 5 \text { th/jumlah } \\
\text { dewan direksi/komisaris, ROA = laba setelah pajak/total aset, LEV = Piutang jangka } \\
\text { panjang/total aset. }\end{array}$} \\
\hline
\end{tabular}

Seorang dewan direksi baru membutuhkan waktu berkisar antara tiga dan lima tahun untuk memperoleh pemahaman yang memadai mengenai perusahaan. Sehingga dengan adanya anggota dewan dengan masa jabatan lebih dari 5 tahun memiliki pengetahuan yang cukup untuk melakukan manajemen laba. Penelitian dengan hasil sama ditunjukkan oleh Park \& Shin (2004) bahwa tidak ditemukanya pengaruh masa jabatan anggota dewan direksi/komisaris luar dengan penurunan perilaku manajemen laba.

\section{Kesimpulan dan Saran}

Dari hasil penelitian tentang pengaruh board diversity terhadap manajemen laba, maka dapat ditarik kesimpulan bahwa:

Pertama, perusahaan yang dipimpin oleh wanita maupun pria tidak berpengaruh terhadap manajemen laba, dewan direksi/komisaris dengan latar belakang pendidikan ekonomi dan bisnis, umur dewan 40-45 tahun dan juga latar belakang etnis Tionghoa tidak mempengaruhi adanya praktek manajemen laba. Persentase pimpinan perusahaan wanita yang rendah serta persentase anggota dewan dengan umur 40-45 tahun yang cenderung rendah, latar belakang pendidikan ekonomi dan bisnis, serta anggota dewan dengan latar belakang etnis Tionghoa tidak berpengaruh terhadap adanya praktik manajemen laba. 
Kedua, keberadaan dewan direksi/komisaris dengan latar belakang masa jabatan lebih dari 5 tahun cenderung berani untuk melakukan manajemen laba. Seorang dewan direksi baru membutuhkan waktu berkisar antara tiga dan lima tahun untuk memperoleh pemahaman yang memadai mengenai perusahaan. Sehingga dengan adanya anggota dewan dengan masa jabatan lebih dari 5 tahun memiliki pengetahuan yang cukup untuk melakukan manajemen laba.

Adapun keterbatasan dari penelitian ini meliputi: pertama, terdapat faktor subjektivitas dalam memperoleh data yang berkaitan dengan minority (etnis Tionghoa) karena peneliti melakukan identifikasi berdasarkan foto yang ada pada laporan tahunan perusahaan tanpa melakukan crosscheck data dengan sumber lain seperti website perusahaan.

Kedua, penelitian ini menggunakan data panel yang mengharuskan terpenuhinya setiap unsur penelitian selama waktu observasi. Akibat dari hal tersebut sampel yang diperoleh cukup sedikit, sehingga perlu dilakukan penambahan jumlah tahun observasi sehingga sampel yang diperoleh lebih banyak.

Berdasarkan keterbatasan penelitian yang telah diungkapkan, maka diberikan saran untuk penelitian selanjutnya meliputi: Pertama, penelitian selanjutnya dapat menambahkan tahun observasi sehingga sampel yang diperoleh bisa lebih maksimal. Kedua, penelitian selanjutnya dapat melakukan crosscheck pada website resmi perusahaan yang bersangkutan sehingga variabel independen tentang etnis Tionghoa bisa dipertanggungjawabkan.

\section{Referensi}

Adams, R. B., \& Ferreira, D. (2009). Women in the boardroom and their impact on governance and performance. Journal of Financial Economics, 291 - 309.

ARARAT, M., AKSU, M., \& CETIN, A. T. (2010). Impact of Board Diversity on Boards' Monitoring Intensity and Firm Performance: Evidence from the Istanbul Stock Exchange. 1-33.

Carter, D. A., Simkins, B. J., \& Simpson, W. G. (2002). Corporate Governance, Board Diversity, and Firm value.

Crawford, M. E. (2006). Trnasformation: women, gender and psycology. Mc Graw Hill.

Darmadi, S. (2011). Board diversity and firm performance: the Indonesian evidence. Corporate Ownership and Control, 8, pp. 138 .

Dechow, P. M., Sloan, R. G., \& Sweeney, A. P. (1995). Detecting Earnings Management. The Accounting Review, 193-225.
Fama, E. F. (1970). Efficient Capital Market A Review of Theory and Empirical Work. Journal of Finance.

Fischer, M., \& Rosenzweig, K. (1995). Attitude of student and accounting practitioners concerning the ethical acceptability of earnings management. Journal of Business Ethics 14, 433-444.

Gavious, I., Segev, E., \& Yosef, R. (2012). Female directors and earnings management in high-technology firms. Pasific Accounting Review Vol 24, 4-32.

Gumanti, T. A., \& Utami, E. S. (2002). Bentuk pasar efisien dan pengujianya. Jurnal Akuntansi dan Keuangan Vol.4, 54-68.

Hambrick, D. C., \& Mason, P. A. (1984). Upper Echelons: The Organisation as a Refflection of its Top Managers. Academy of Management Review, 193-206.

Jensen, M. C., \& Meckling, W. H. (1976). Theory of the Firm: Managerial Behavior, Agency Costs, and Ownership Structure. Journal of Financial Economics 3

Jones, C. P. (1998). Investment: Analysis and Management. John wiley and Son.

Kesner, I. F. (1988). Directors' Characteristics and Committee Membership: An Investigation of Type, Occupation, Tenure and Gender. Academy of Managemet Journal Vol.31.

Kieso, D. E., Weygandt, J. J., \& Warfield, T. D. (2011). Intermidiate Accounting. Vol.1 IFRS Edition.

Kusumastuti, S., Supatmi, \& Sastra, P. (2007). Pengaruh Board Diversity Terhadap nilai perusahaan dalam Perspektif Corporate Governance. JURNAL AKUNTANSI DAN KEUANGAN, VOL 9 NO, 2, 88-98.

Milliken, F. J., \& Martins, L. L. (1996). Searching for Common Threads: Understanding the Multiple Effect of Diversity in Organizational Groups. Academy of Management Review Vol.21, 402-433.

Miller, T., \& Triana, M. d. (n.d.). Demographic Diversity in the Boardroom: Mediators of the board Diversity-Firm Performance Relationship. Journal of Management Studies, 2009.

Monks, R. A., \& Minow, N. (2003). Corporate Governance 3rd Edition. Blackwell publishing.

Nachrowi, N. D., dan Usman, H. (2006). Pendekatan Populer dan Praktis Ekonometrika Untuk Analisis Ekonomi dan Keuangan. Jakarta: Lembaga Penerbit Fakultas Ekonomi Universitas Indonesia.

Park, Y. W., \& Shin, H. H. (2004). Board composition and earnings management in Canada. Journal of Corporate Finance.

Peni, E., \& Vahamaa, S. (2010). Female executives and earnings manajement. Managerial Finance, vol 36, 629-645.

Permana, A. E. (2012). Analisis Faktor-Faktor yang Mempengaruhi Ketepatan Waktu Laporan Keuangan (Studi pada perusahaan manufaktur yang terdaftar di BEI 2008-2010. Skripsi Sarjana S1 Fakultas Ekonomi Universitas Lampung. 
Pfeffer, J. (1983). Organizational demography: Implication for management. California Management Review.

Roychowdhury, S. (2006). Earning Management through Real Activities Manipulation. Journal of Accounting and Economics, 154.

SAK. (2012). Standar Akuntansi Keuangan. Ikatan Akuntan Indonesia.

Scott, W. R. (2009). Financial Accounting Theory. 5th. Toronto: Pearson Prentice Hall.
Setyawan, S. (2005). Konteks Budaya Etnis Tionghoa dalam Manajemen Sumber Daya Manusia. Jurnal manajemen dan Bisnis.

Sulistyanto, S. (2008). Manajemen Laba: Teori dan Model Empiris. PT. Gramedia Widiasarana. Jakarta.

Watts, R. L., \& Zimmerman, J. L. (1990). Positive Accounting Theory: A Ten Years Perspective. The Accounting Review.

Williams, K. Y., \& O'Reilly, C. A. (1998). Demography and Diversity in Organizations: A review of 40 years of research. Research in Organizational Behavior, Volume 20, 77-140. 